\title{
Nucleotide Sequence of the Sporulation Operon, spoIIIE, of Bacillus subtilis
}

\author{
By P. D. BUTLER ANd J. MANDELSTAM* \\ Microbiology Unit, Department of Biochemistry, University of Oxford, South Parks Road, \\ Oxford OXI $3 Q U, U K$
}

(Received 17 December 1986; revised 25 February 1987)

\begin{abstract}
A fragment of Bacillus subtilis DNA 3490 bp long, capable of complementing spoIIIE mutations, was sequenced. The region of the fragment that encodes functions required for sporulation was delimited using integrational plasmids. Sequencing showed that this region contained an operon with two open reading frames together with associated ribosome-binding sites. The deduced translation products would be polypeptides of 518 and 252 amino acid residues. Several sequences resembling promoters recognized by RNA polymerase containing $\sigma^{29}$ occur in the region preceding the larger open reading frame. Although no transcription-termination signal was identified downstream of the smaller coding region, analysis with integrational plasmids and determination of the size of spoIIIE messenger RNA suggest that the locus does not contain a third gene.
\end{abstract}

\section{INTRODUCTION}

Formation of spores by Bacillus subtilis requires the sequential expression of about 150 genes (Errington et al., 1985). Cloning of a sporulation gene is the first step in establishing its position in the dependence pattern of sporulation gene expression either by experiments with DNARNA hybridization (Savva \& Mandelstam, 1985) or by construction of a suitable (e.g. lacZ) gene fusion (Errington, 1986). A tentative pattern of the pathway of sporulation gene expression has been described by Turner et al. (1986).

Mutations at the spoIIIE locus arrest spore development after formation of the prespore protoplast, and block certain later events known to occur only in the spore compartment, e.g. expression of spoVA (Errington \& Mandelstam, 1986). They have no effect on the synthesis in the mother cell compartment of the enzyme dipicolinic acid synthase, a product of the spoVF operon (J. Errington \& J. Mandelstam, unpublished results).

In this paper the sequence of a $3490 \mathrm{bp}$ fragment of DNA capable of complementing all known spoIIIE mutations is described.

\section{METHODS}

Bacterial strains, bacteriophages and plasmids. These are described in Table 1, with details of their sources and construction.

General methods. Replicative forms of M13mp18 and M13mp19 DNA were obtained from Pharmacia. Dephosphorylated SmaI-cleaved M13mp10 DNA was from Amersham. Restriction enzymes were used under conditions described by Maniatis et al. (1982).

Electrophoresis of DNA was performed through $1 \%(\mathrm{w} / \mathrm{v})$ agarose (Sigma, type II) with TBE buffer (90mM-Tris base, $90 \mathrm{~mm}$-boric acid, $2.5 \mathrm{~mm}-\mathrm{Na}_{2}$ EDTA, pH 8.3). Gel loading buffer $[40 \%(\mathrm{w} / \mathrm{v})$ sucrose, $0.25 \%(\mathrm{w} / \mathrm{v})$ bromophenol blue] was added to DNA in TC buffer $(10 \mathrm{mM}$-Tris/ $\mathrm{HCl}, 1 \mathrm{~mm}$-cyclohexanediaminetetra-acetic acid, pH 7.5). DNA was visualized by ethidium bromide fluorescence. Preparative electrophoresis at $4{ }^{\circ} \mathrm{C}$ was done with low-melting-point agarose (1\%,BRL). DNA was extracted from agarose as described by Savva \& Mandelstam (1984).

Ligation mixtures in $10 \mathrm{~mm}-\mathrm{Tris} / \mathrm{HCl}\left(\mathrm{pH} \mathrm{7.5),} 50 \mathrm{~mm}-\mathrm{NaCl}, 10 \mathrm{~mm}-\mathrm{MgCl}_{2}, 5 \mathrm{~mm}-\mathrm{DTT}, 1 \mathrm{~mm}-\mathrm{ATP}, 1\right.$ unit $\mathrm{T}_{4}$ DNA ligase (BCL), containing approximately $20 \mathrm{ng}$ vector DNA with a 5-10 molar excess of the DNA to be cloned, in a final volume of $10 \mu \mathrm{l}$, were incubated overnight at $4{ }^{\circ} \mathrm{C}$. 
Table 1. Bacterial strains, bacteriophages and plasmids

\section{Bacteria}

E. coli

JM103

JM107

GM48

B. subtilis

168

CU267

36

47

82

Bacteriophages

M13mp10

$\left.\begin{array}{l}\text { M13mp18 } \\ \text { M13mp19 }\end{array}\right\}$

$\phi 105 \mathrm{~J} 27$

$\phi 105 \mathrm{~J} 30$

$\phi 105 \mathrm{~J} 31$

Stock plasmids

pUC18

pSGMU2
Genotype

$\Delta$ (lac-pro) thi rpsL supE endA sbcB15

$\mathrm{F}^{\prime}$ traD36 proAB lacI ${ }^{\mathrm{Z}} \mathrm{Z} \Delta M 15$

$\Delta$ (lac-pro) thi supE endA relAl gyrA 96 hsdR 17

$\mathrm{F}^{\prime}$ traD36 proAB lacI $\mathrm{Z} \Delta \mathrm{M} 1 \mathrm{~S}$

thi thr leu lac Y galK galT ara tonA tsx dam dcm supE

trpC2

leuB16 ilvB2 trpC2

trpC2 spollIE36

trpC2 spoIIIE47

metC3 leu-8 tal-1 spoIIIE82

Relevant characteristics

Sequencing vectors

Cloning vector

spoIIIE ${ }^{+}$

spoIIIE ${ }^{+}$

Relevant characteristics

$A^{R}$

$\mathrm{Ap}^{\mathrm{R}} \mathrm{Cm}^{\mathrm{R}}$ integrational plasmid
Source/reference

Messing et al. (1981)

Yanisch-Perron et al. (1985)

Marinus (1973)

Laboratory stock

S. A. Zahler*

Piggot (1973)

Piggot (1973)

Hranueli et al. (1974)

\section{Reference}

Messing (1983)

Norrander et al. (1983)

Norrander et al. (1983)

Jones \& Errington (1987)

Errington \& Jones (1987)

Errington \& Jones (1987)

\section{Reference}

Norrander et al. (1983)

Fort \& Errington (1985)

Constructed plasmids
pSGMU203
pSGMU204
pSGMU205
pSGMU208
pSGMU209
pSGMU210
pSGMU211
pSGMU212

\begin{tabular}{|c|}
\hline Construction $†$ \\
\hline 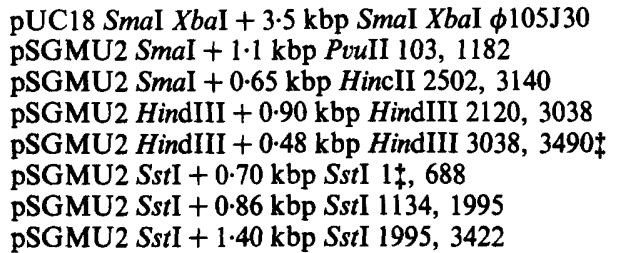 \\
\hline
\end{tabular}

*S. A. Zahler, Genetics and Development Department, Cornell University, Ithaca, NY, USA.

† Shows enzymes used in the preparation of vector DNA followed by the size of the cloned fragment, the enzymes used to generate the fragment and its origin. Plasmid pSGMU203 was the source of fragments for the other seven plasmids. Positions of the ends of each fragment from the sequence shown in Fig. 3 are given.

$\ddagger$ Two constructions involved the use of restriction sites in the polylinker region of pSGMU203 (derived from pUC18) which are adjacent to termini of the $3.5 \mathrm{kbp}$ fragment. The numbers represent the end of the sequenced region adjacent to the sites in the polylinker, not the actual position in Fig. 3.

Fragments of DNA generated with $\mathrm{Ha}$ II were ligated to SmaI-cleaved vectors after removal of protruding $3^{\prime}$ ends with DNA polymerase I Klenow fragment. DNA (approximately $100 \mathrm{ng}$ ) was incubated with Klenow fragment (1 unit) in $10 \mathrm{~mm}$-Tris/ $\mathrm{HCl}$ (pH 8.0), $5 \mathrm{mM}-\mathrm{MgCl}_{2}$ for $30 \mathrm{~min}$ at $37^{\circ} \mathrm{C}$. Deoxynucleotide triphosphates $(100 \mu \mathrm{M}$ each) were added and the incubation continued for a further $1 \mathrm{~h}$ at room temperature.

DNA-DNA hybridizations were done as described by Southern (1975). RNA for 'Northern' hybridizations was prepared according to Savva \& Mandelstam (1985). After electrophoresis through $1.5 \%$ (w/v) agarose in the presence of formaldehyde, as described by Maniatis et al. (1982), RNA was transferred and hybridized according to Savva \& Mandelstam (1985).

Escherichia coli techniques. Strains of E. coli were made competent as described by Fort \& Piggot (1984). Transformants of strains JM103 and JM107 were screened for plasmids containing DNA inserts by their inability to hydrolyse 5-bromo-4-chloro-3-indolyl $\beta$-D-galactopyranoside (Messing, 1983).

Plasmids were prepared by the alkaline lysis method of Birnboim \& Doly (1979) followed by CsCl/ethidium bromide density-gradient centrifugation (Lovett \& Keggins, 1979). Replicative-form DNA was prepared from cells infected with M13 vectors and grown as described in the Amersham M13 Cloning and Sequencing Handbook. DNA was extracted and purified by the $\mathrm{CsCl} /$ ethidium bromide centrifugation method used for plasmid preparation. Typically this was done to 'turn-around' cloned fragments of DNA to permit sequencing from the other end. 
DNA sequencing. This was done by the dideoxynucleotide chain termination method of Sanger et al. (1977) as described in the Amersham M13 Cloning and Sequencing Handbook. Sequencing primer was annealed to template DNA by heating the annealing mixture at $100^{\circ} \mathrm{C}$ for $3 \mathrm{~min}$ then allowing it at least $15 \mathrm{~min}$ to cool to room temperature (New England Biolabs Sequencing Manual). Sequencing reactions were done with $\alpha-\left[{ }^{35}\right.$ S $] \mathrm{dATP}$ (Amersham), at $37^{\circ} \mathrm{C}$. All nucleotides were from BCL.

The C-test described by Messing (1983) was used to check certain M13 clones for the correct insert and its orientation. Samples $(20 \mu \mathrm{l})$ of phage supernatant to be tested and of the phage which contained the appropriate complementary insert were mixed with $4 \mu 100 \mathrm{mM}-\mathrm{Na}_{2}$ EDTA $(\mathrm{pH} 8.0)$, containing $1 \%(\mathrm{w} / \mathrm{v}) \mathrm{SDS}, 50 \%(\mathrm{w} / \mathrm{v})$ glycerol and $0.1 \%$ bromophenol blue, and incubated for $1 \mathrm{~h}$ at $65{ }^{\circ} \mathrm{C}$ prior to electrophoresis.

B. subtilis techniques. B. subtilis was made competent for transformation by the method of Anagnostopoulos \& Spizizen (1961) as modified by Jenkinson (1983). Chloramphenicol was added at $5 \mu \mathrm{g} \mathrm{ml}^{-1}$ to nutrient agar for selection of chloramphenicol-resistant transformants. Selection for $\mathrm{Spo}^{+}$transformants and transductants was on Schaeffer's sporulation agar (Schaeffer et al., 1965) with chloroform treatment (Hoch, 1971) as described by Errington \& Jones (1987).

Sporulation was induced by the resuspension method of Sterlini \& Mandelstam (1969) and times after induction are given as $t_{0}, t_{1}, t_{2}$, etc. The incubation temperature was $37^{\circ} \mathrm{C}$. Alkaline phosphatase activity was assayed according to Errington \& Mandelstam (1983). Heat-resistance was determined by heating samples of resuspended cultures, taken at $t_{9}$ and diluted tenfold with resuspension medium, at $80^{\circ} \mathrm{C}$ for $15 \mathrm{~min}$. The number of survivors was determined by plating dilutions on nutrient agar (Oxoid).

\section{RESULTS}

Isolation, characterization and complementation efficiency of recombinant bacteriophages $\phi 105 J 30$ and $\phi 105 \mathrm{~J} 31$

Two derivatives of $\phi 105 \mathrm{~J} 27$ which transduced a spoIIIE mutant to $\mathrm{Spo}^{+}$were isolated by Errington \& Jones (1987) from a genomic library formed by cloning size-fractionated ( $2-4 \mathrm{kbp})$ $M b o I$ partially digested $B$. subtilis 168 DNA into the unique BamHI cloning site of $\phi 105 \mathrm{~J} 27$ (see Fig. $1 b$ ). The ability of $\phi 105 \mathrm{~J} 30$ and $\phi 105 \mathrm{~J} 31$ to complement the spoIIIE36 mutation was demonstrated by subsequently inducing the phage in $\mathrm{Spo}^{+}$transductants and repeating the transduction of strains carrying spoIIIE36 to $\mathrm{Spo}^{+}$. Both phages were also able to transduce spoIIIE47 and spoIIIE82 mutants to Spo $^{+}$as shown by the cross-streaking test on Schaeffer sporulation agar (Errington \& Jones, 1987).

The efficiency of sporulation was compared in the three spoIIIE mutants and their $\phi 105 \mathrm{~J} 30$ lysogen derivatives. Production of alkaline phosphatase was monitored at $t_{4}$ to ensure that sporulation was proceeding normally at least up to stage II and heat resistance was measured at $t_{9}$ (see Methods). Since $\phi 105 \mathrm{~J} 27$ and its derivatives are temperature-inducible (Jones \& Errington, 1987) incubation at $37^{\circ} \mathrm{C}$, instead of $30^{\circ} \mathrm{C}$, could reduce viability by causing induction of the phage. Accordingly, a Spo ${ }^{+}$strain, CU267, and a CU267 $\phi 105 \mathrm{~J} 27$ lysogen were also induced to sporulate by resuspension at $37^{\circ} \mathrm{C}$. Sporulation in all the $\phi 105$ lysogens was normal as adjudged by the numbers of heat-resistant colony-forming units (Table 2 ). The temperature-inducible nature of $\phi 105 \mathrm{~J} 27$, and presumably of its derivatives, had no noticeable effect on the yield of spores.

\section{Table 2. Complementation of spoIIIE mutations by phage $\phi 105 J 30$}

Strains were lysogenized by streaking on agar spread with phage $\phi 105 \mathrm{~J} 30$ (Errington \& Jones, 1987). Formation of heat-resistant spores was determined at $t_{9}$ after resuspension in sporulation medium at $37^{\circ} \mathrm{C}$ (Sterlini \& Mandelstam, 1969).

$\begin{array}{lcr}\text { Strain } & \overbrace{\text { Non-lysogen }}^{\text {Heat-resistant spores } \mathrm{ml}^{-1}} & \text { Lysogen* } \\ \text { CU267 (wild-type) } & 2 \cdot 1 \times 10^{8} & 2.5 \times 10^{8} \\ 36 & <10^{3} & 5.6 \times 10^{8} \\ 47 & 1 \times 10^{4} & 2 \times 10^{8} \\ 82 & 1.4 \times 10^{4} & 1 \times 10^{8} \\ & * \text { CU267 was lysogenized with } \phi 105 \mathrm{~J} 27 .\end{array}$




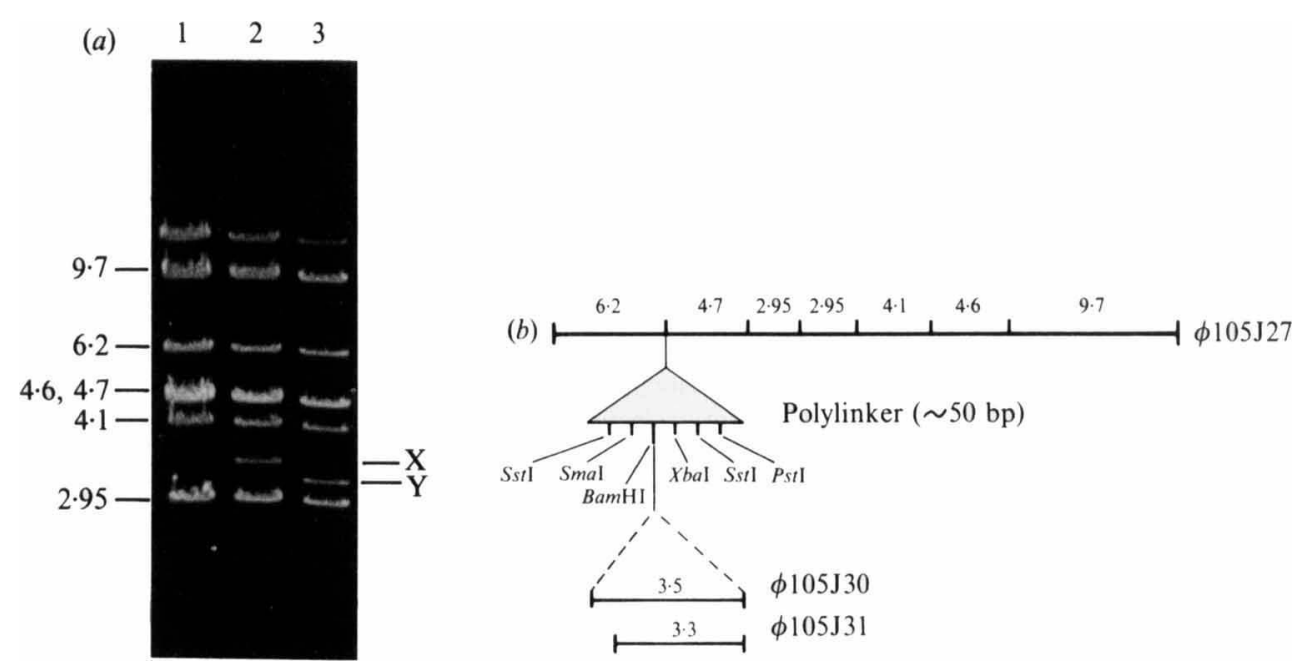

Fig. 1. Restriction endonuclease analysis of bacteriophages $\phi 105 \mathrm{~J} 30$ and $\phi 105 \mathrm{~J} 31$. (a) DNA from $\phi 105 \mathrm{~J} 27$ and the two spoIIIE bacteriophages $\phi 105 \mathrm{~J} 30$ and $\phi 105 \mathrm{~J} 31$ derived from it were digested with SmaI and $X b a I$ and subjected to electrophoresis in agarose gels. Lanes: $1, \phi 105 \mathrm{~J} 27 ; 2, \phi 105 \mathrm{~J} 30$; $3, \phi 105 \mathrm{~J} 31$. Figures for the sizes of the Smal fragments (kbp) are taken from Jones \& Errington (1987). (b) Restriction map of $\phi 105 \mathrm{~J} 27$ showing $S m a I$ sites and the polylinker section containing the BamHI cloning site into which DNA was ligated forming $\phi 105 \mathrm{~J} 30$ and $\phi 105 \mathrm{~J} 31$. (The inserts in $\phi 105 \mathrm{~J} 30$ and $\phi 105 \mathrm{~J} 31$ are not drawn to the same scale as the map of $\phi 105 \mathrm{~J} 27)$.

Preliminary restriction mapping revealed that $\phi 105 \mathrm{~J} 30$ and $\phi 105 \mathrm{~J} 31$ contained fragments of B. subtilis DNA of $3.5 \mathrm{kbp}$ and $3.3 \mathrm{kbp}$ respectively. Fig. 1(a) shows the fragments of DNA generated by digestion of DNA from $\phi 105 \mathrm{~J} 27, \phi 105 \mathrm{~J} 30$ and $\phi 105 \mathrm{~J} 31$ with the restriction endonucleases SmaI and $X b a I$. The pattern obtained with $\phi 105 J 27$ DNA (Fig. $1 a$, lane 1) was essentially identical to that obtained when $S m a I$ was used alone, since the unique $X b a I$ site in the polylinker region is adjacent to a SmaI site (see Fig. $1 b$ ). Any DNA cloned into the unique BamHI site of $\phi 105 \mathrm{~J} 27$ is thus immediately flanked by sites for SmaI and $\mathrm{XbaI}$. Provided that neither enzyme cuts within the insert, as is the case with the inserts of $\phi 105 \mathrm{~J} 30$ and $\phi 105 \mathrm{~J} 31$, double digestion with both enzymes provides a convenient means of excising the cloned fragments precisely. The cloned fragments from $\phi 105 \mathrm{~J} 30$ and $\phi 105 \mathrm{~J} 31$ are labelled $X(3.5 \mathrm{kbp})$ and Y (3.3 kbp) respectively, in Fig. $1(a)$. All three lanes in Fig. $1(a)$ show an extra band above the bands at $9.7 \mathrm{kbp}$. This results from annealing of 9.7 and $6.2 \mathrm{kbp}$ fragments mediated by the phage cohesive ends.

The use of restriction enzymes, such as HindIII or Sst I, that cleave both within the insert and the vector confirmed that the inserts differed only slightly in length. The difference of $0.2 \mathrm{kbp}$ presumably results from the absence of one $M b o I$ fragment from the $\phi 105 \mathrm{~J} 31$ insert (this was deduced from the sequence). Both inserts are in the same orientation, the difference between them being at the SmaI end.

\section{Construction of plasmid pSGMU203}

To construct a detailed restriction map of the fragments which complement all three spoIIIE mutations, the $3.5 \mathrm{kbp} S m a \mathrm{I}-\mathrm{XbaI}$ fragment from $\phi 105 \mathrm{~J} 30$ was subcloned into the $E$. coli plasmid pUC18 (Norrander et al., 1983). Phage DNA digested with SmaI and XbaI was electrophoresed through low-melting-point agarose. The appropriate fragment was isolated and ligated with similarly digested pUC18. To avoid any problems that might be caused by the $E$. coli $\mathrm{K} 12$ restriction system, strain JM107 was used as the recipient in the initial transformation. Transfer to restriction-proficient strains JM103 and GM48 was then possible. The latter strain is $\mathrm{Dam}^{-}$and $\mathrm{Dcm}^{-}$; thus plasmid DNA isolated from this strain can be digested by restriction endonucleases (such as $B c I I$ ) inhibited by methylation at their recognition sites. The resultant 


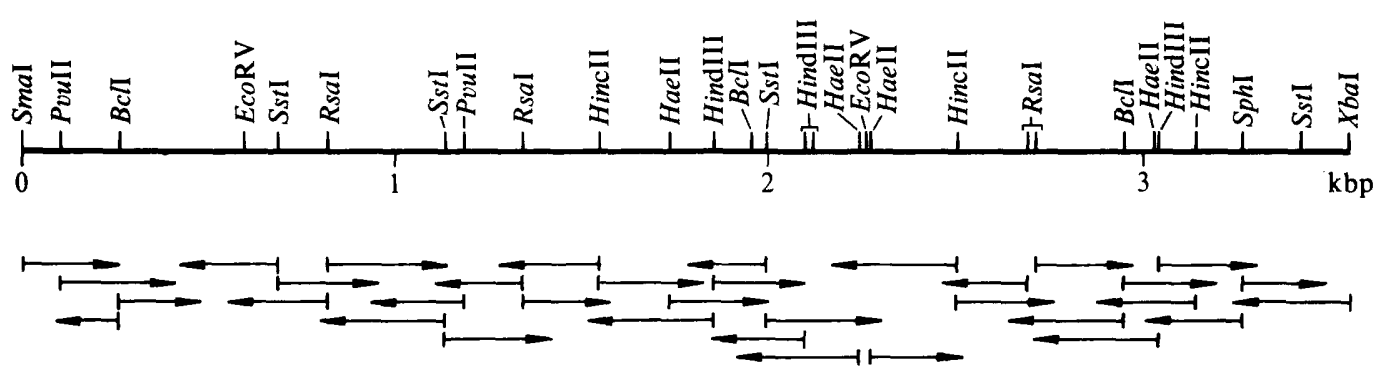

$0.1 \mathrm{kbp}$

$\longmapsto$

Fig. 2. Partial restriction map of the $3.5 \mathrm{kbp}$ spoIIIE fragment from $\phi 105 \mathrm{~J} 30$. The map was derived from digests of pSGMU203 DNA. The sites shown are mostly those used to construct M13 sequencing vector clones. The arrows indicate that start and extent of the sequences obtained from these clones. The left-hand end of the map corresponds to the SmaI site of $\phi 105 \mathrm{~J} 30$.

plasmid, named pSGMU203, was used to derive the restriction map shown in Fig. 2. Sites shown are principally those that were used for DNA sequencing. Agarose gel electrophoresis failed to detect the very small fragments generated by HaeII, HindIII and RsaI at positions 2240 to 2276,2100 to 2120 and 2689 to 2712 respectively (as numbered in the nucleotide sequence shown in Fig. 3). The presence of the extra sites for these enzymes was deduced from the nucleotide sequence.

Plasmid pSGMU203 DNA was also tested for the ability to transform spoIIIE strains to Spo ${ }^{+}$. More than $1 \times 10^{4} \mathrm{Spo}^{+}$transformants per $\mu \mathrm{g}$ DNA were obtained with strains 47 and 82 . The other strain which was used in the initial cloning in $\phi 105 \mathrm{~J} 27$, spoIIIE36, gave only about $10^{3}$ transformants per $\mu \mathrm{g}$ DNA. This difference could be due to the mutation being very near to the end of the cloned fragment with a corresponding reduction in the incidence of recombination.

Fragments from pSGMU203 were subcloned further into the integrational plasmid pSGMU2 (Fort \& Errington, 1985) primarily for use in determining the extent of the spoIIIE functional unit within the cloned fragment, but also to provide a more convenient source of fragments for determination of the nucleotide sequence.

To confirm that the $3.5 \mathrm{kbp}$ fragment cloned in pSGMU203 had not resulted from ligation of non-adjacent $M b o I$ fragments of $B$. subtilis chromosomal DNA, a Southern blotting experiment (Southern, 1975) was performed as follows. Chromosomal DNA from B. subtilis was digested with SstI or PvuII, subjected to electrophoresis, blotted and then probed with a nick-translated sample of pSGMU203. Hybridization occurred to a Pvull fragment of $1.1 \mathrm{kbp}$ and to Sst fragments of $1.43,0.86$ and $0.45 \mathrm{kbp}$, as expected from the restriction map of pSGMU203 (data not shown). This confirms that the segment is a part of the $B$. subtilis chromosome that has not suffered rearrangement.

\section{Determination of nucleotide sequence}

Restriction fragments of the $3.5 \mathrm{kbp} S m a \mathrm{I}-X b a \mathrm{I}$ fragment were derived from plasmid pSGMU203 or pSGMU2 derivatives (see Table 1) and subcloned into M13 chain termination sequencing vectors. The origins of the segments are shown in Fig. 2 with the maximum extent of sequence derived from each clone. The complete nucleotide sequence is shown in Fig. 3. Both strands of the fragment were sequenced to the right of the SstI site at position 688. The remaining section of the fragment was sequenced from at least two independent clones unless both strands had been sequenced.

It was necessary to substitute dITP for dGTP to enable sequencing of both strands around the region containing two HaeII sites at positions 2240 and 2276 to eliminate so-called compressions from sequencing gels.

Autoradiograms were read and recorded using a sonic digitizer (Staden, 1984a). The complete sequence was compiled using the DBUTIL program of Staden (1982). Analysis of the nucleotide 


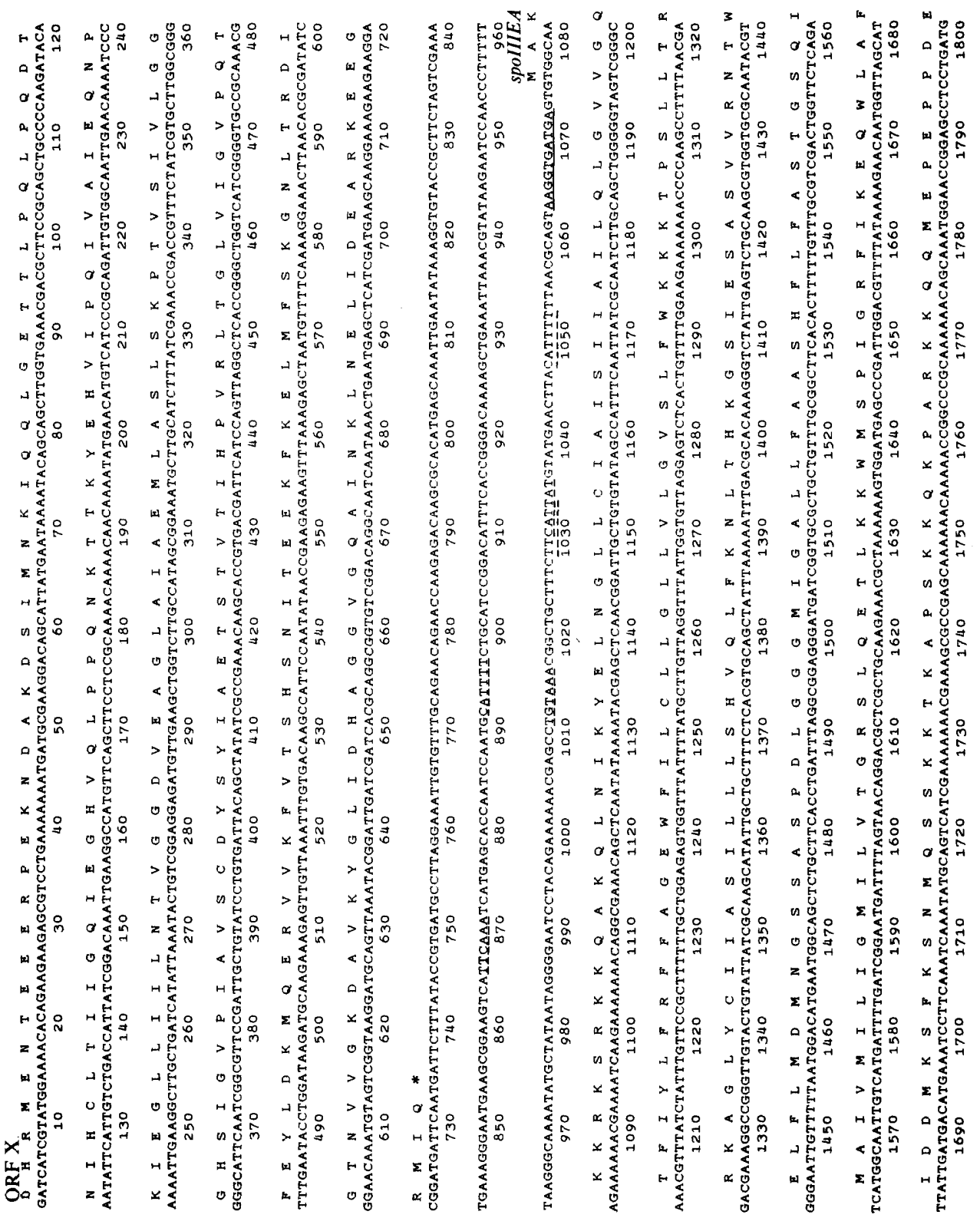




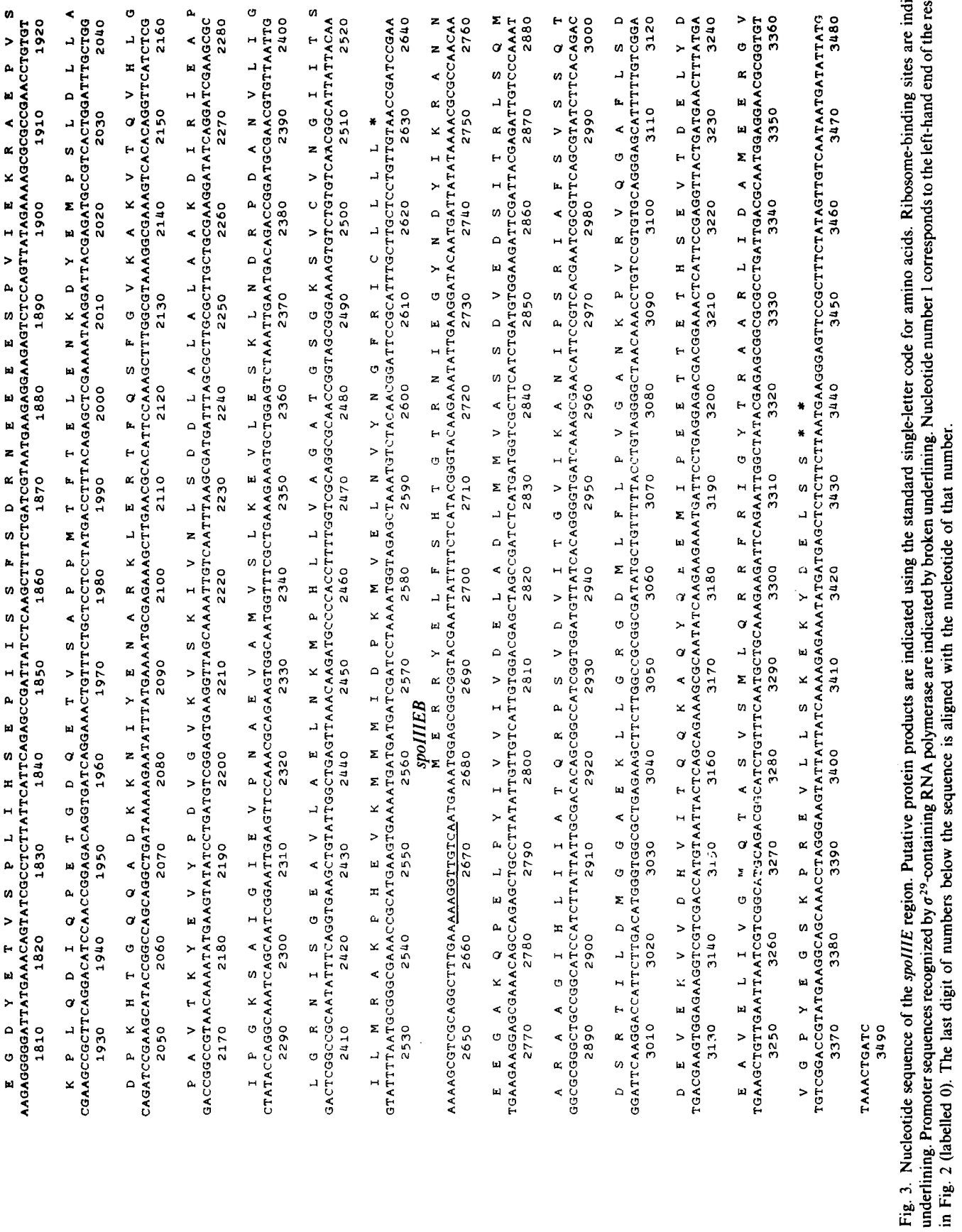


Table 3. Potential ribosome-binding sites and properties of the putative translation products of the spoIIIE operon

\begin{tabular}{|c|c|c|c|c|c|}
\hline \multirow[b]{2}{*}{$\begin{array}{l}\text { spoIIIEA } \\
\text { spoIIIEB } \\
\text { 16S rRNA }\end{array}$} & \multicolumn{4}{|c|}{ Ribosme-hinding sitec* } & \multirow{2}{*}{$\begin{array}{c}\Delta G \dagger \\
\left(\mathrm{kcal} \mathrm{mol}^{-1}\right) \\
-10 \cdot 8 \\
-9.8\end{array}$} \\
\hline & $\begin{array}{r}\mathrm{a} \text { G t } \\
\mathrm{a} \text { a A } \\
3^{\prime} \mathrm{UCU}\end{array}$ & $\begin{array}{l}3 \mathrm{G} \mathrm{t} \\
\mathrm{jG} \mathrm{t} \\
\mathrm{SC} \mathrm{U}\end{array}$ & $\begin{array}{l}G A g g \\
c A a t \\
C U A G\end{array}$ & $\begin{array}{l}\text { c a } \\
\text { t } \mathrm{g}\end{array}$ & \\
\hline \multicolumn{6}{|c|}{ Translation products } \\
\hline \multicolumn{6}{|c|}{$\begin{array}{l}\text { Nucleotide } \\
\text { position§ }\end{array}$} \\
\hline & Start & Stop & $\begin{array}{c}\text { No. of } \\
\text { amino acids }\end{array}$ & $M_{r}$ & $\mathrm{pI} \|$ \\
\hline SpoIIIEA & 1074 & 2627 & 518 & 57291 & 8.9 \\
\hline SPoIIIEB & 2678 & 3433 & 252 & 28143 & $4 \cdot 5$ \\
\hline
\end{tabular}

* Ribosome-binding sites begin at positions 1062 and 2662. Nucleotides complementary to the 3 ' terminus of 16s rRNA are shown in upper case.

† Free energy of base pairing calculated by the rules of Tinoco et al. $(1973) ; 1 \mathrm{kcal}=4 \cdot 184 \mathrm{~kJ}$.

$\ddagger$ The sequence of the $3^{\prime}$ terminus of $B$. subtilis rRNA was taken from McLaughlin et al. (1981).

$\S$ Position of first nucleotide of start codon and last nucleotide before stop codon in Fig. 3 .

|| Estimated according to Martin (1964).

sequence with the ANALYSEQ software package of Staden (1984b) revealed three open reading frames, all of which were on the same strand. This would account for over $80 \%$ of the full coding potential of the fragment. Each open reading frame occurs in a different reading phase. No major open reading frames were found on the other strand. The three open reading frames are at positions 1 to 732,1056 to 2627 and 2576 to 3433 .

The first open reading frame, ORF X in Fig. 3, represents a fragment of a gene whose function is unknown and which is not concerned in sporulation as demonstrated by analysis with integrational plasmids (see below). The remaining two open reading frames were shown to be within regions of the sequenced fragment concerned with spore formation.

Potential ribosome-binding sites were located to define the possible protein products encoded in the open reading frames. Translation products encoded by the regions in the sequence from positions 1074 to 2627 and 2678 to 3433 start with known initiation codons preceded by regions complementary to the $3^{\prime}$ end of $16 \mathrm{~S}$ ribosomal RNA permitting a ribosome-binding interaction (Shine \& Dalgarno, 1974). In accord with the convention of Fort \& Errington (1985) the two sporulation genes coded between 1074 to 2627 and 2678 to 3433 were named spoIIIEA and spoIIIEB respectively. Table 3 shows the ribosome-binding sites and the properties of the translation products. The method of Tinoco et al. (1973) was used to estimate the free energies of the Shine-Dalgarno interactions. Both interactions were considered to be rather weak in view of the accepted notion that the mRNA-16S rRNA interaction in $B$. subtilis is more stringent than that in $E$. coli, with an average free energy value of $-17 \mathrm{kcal}(71 \cdot 1 \mathrm{~kJ}) \mathrm{mol}^{-1}$ as compared with $-11 \mathrm{kcal}\left(46.0 \mathrm{~kJ}\right.$ ) $\mathrm{mol}^{-1}$ (Murray \& Rabinowitz, 1982; Gold et al., 1981). However, the values obtained are acceptable, as Wang \& Doi (1986) have demonstrated the utilization of a ribosomebinding site by $B$. subtilis with an estimated free energy for the Shine-Dalgarno interaction of $-9 \cdot 2 \mathrm{kcal}(38.5 \mathrm{~kJ}) \mathrm{mol}^{-1}$.

Transcription-initiation signals are summarized in Table 4. Three regions resembling $\sigma^{29}$ promoter sequences can be located in the region between the end of ORF X and the start of the putative spoIIIEA coding region. While there is good agreement with the consensus $\sigma^{29}$ promoter sequence in terms of the most highiy conserved bases (Cowing et al., 1985), there are discrepancies in the spacing between the -35 and -10 regions. Similarities to other promoter sequences were nowhere near as marked. For example, a $\sigma^{32}-35$ region could be seen at position 868 and a $\sigma^{43}-19$ region at 977 . However, no corresponding -10 and -35 regions could be seen. 
Table 4. Potential transcription-initiation signals in the spoIIIE locus

The consensus sequence for $\sigma^{29}$ is taken from Cowing et al. (1985) and the most highly conserved bases are underlined.

$\begin{array}{lccc}\begin{array}{c}\text { Nucleotide } \\ \text { position* }\end{array} & -35 & \text { Spacer } & -10 \\ 865 & \text { TTCAAA } & 20 & \text { CATTTT } \\ 1010 & \text { TGTAAA } & 13 & \text { CATTAT } \\ 1027 & \text { TTCATT } & 13 & \text { CATTTT } \\ \sigma^{29} \text { consensus } & \text { TTNAAAA } & 14-17 & \text { CATAT }\end{array}$

* Position in Fig. 3.

Table 5. Analysis of the spoIIIE region using integrational plasmids

B. subtilis strain 168 was transformed with each integrational plasmid and chloramphenicol-resistant transformants were selected. A transformant resulting from each plasmid was induced to sporulate by resuspension (Sterlini \& Mandelstam, 1969). Sporulation was monitored at $t_{4}$ for alkaline phosphatase. The formation of heat-resistant spores at $t_{9}$ was determined. Survivors were plated on nutrient agar containing chloramphenicol $\left(5 \mu \mathrm{g} \mathrm{ml}^{-1}\right)$.

$\begin{array}{cccc}\begin{array}{c}\text { Integrational } \\ \text { plasmid }\end{array} & \begin{array}{c}\text { Transformants per } \\ \mu \text { g plasmid DNA }\end{array} & \begin{array}{c}\text { Phenotype } \\ \text { PSGMU204 }\end{array} & \begin{array}{r}\text { Heat-resistan } \\ \text { spores } \text { ml }^{-1}\end{array} \\ \text { pSGMU205 } & 1.1 \times 10^{4} & \text { Spo }^{+} & 2.1 \times 10^{8} \\ \text { pSGMU208 } & 0.65 \times 10^{4} & \text { Spo }^{-} & 1 \times 10^{4} \\ \text { pSGMU209 } & 0.40 \times 10^{3} & \text { Spo }^{-} & <1 \times 10^{3} \\ \text { pSGMU210 } & 2.60 \times 10^{3} & \text { Spo }^{+} & 3.4 \times 10^{8} \\ \text { pSGMU211 } & 1.5 \times 10^{3} & \text { Spo }^{+} & 1 \times 10^{8} \\ \text { pSGMU212 } & 0.85 \times 10^{3} & \text { Spo }^{-} & 1 \times 10^{5} \\ \text { SSG } & \text { Spo }^{-} & 2 \times 10^{5}\end{array}$

\footnotetext{
* Examination of colonies on Schaeffer's agar containing chloramphenicol for the presence of phase-bright spores.
}

No obvious stem-loop structure resembling a potential transcription-termination signal can be found in the short region downstream of the spoIIIEB coding region. Thus, the existence of a third gene in the operon could not be precluded on sequence data alone.

The region of the complete sequence labelled ORF $X$ in Fig. 3 represents the C-terminal fragment of an ORF of unknown function. Again, no transcription-termination sequence is obvious in the region between the end of ORF $\mathrm{X}$ and that start of spoIIIEA.

\section{Delimitation of the spoIIIE transcriptional unit using integrational plasmids}

The restriction fragments cloned into the integrational plasmid pSGMU2 span the full length of the $3.5 \mathrm{kbp}$ fragment. Transformation of competent wild-type $B$. subtilis with a plasmid, incapable of replicating in this host, containing homologous DNA and a selectable antibiotic resistance can result in a single recombination event similar to that when bacteriophage $\lambda$ integrates into the $E$. coli chromosome. When the whole of the region of homology is contained within a transcription unit, disruption of that unit must occur, giving rise to a mutant phenotype. If only part of the region of homology is within the functional unit, disruption with change in phenotype does not take place (Piggot et al., 1984).

Plasmids used in such an analysis of the spoIIIE locus are described in Table 1. The position of the cloned fragments relative to the open reading frames is shown in Fig. 4. The Spo phenotypes of chloramphenicol-resistant transformants were characterized by $(a)$ their appearance when patched onto Schaeffer's sporulation agar, $(b)$ examination under the phasecontrast microscope, and $(c)$ the incidence of heat-resistant spores in cultures induced to sporulate by the resuspension method of Sterlini \& Mandelstam (1969). The results are given in Table 5. 


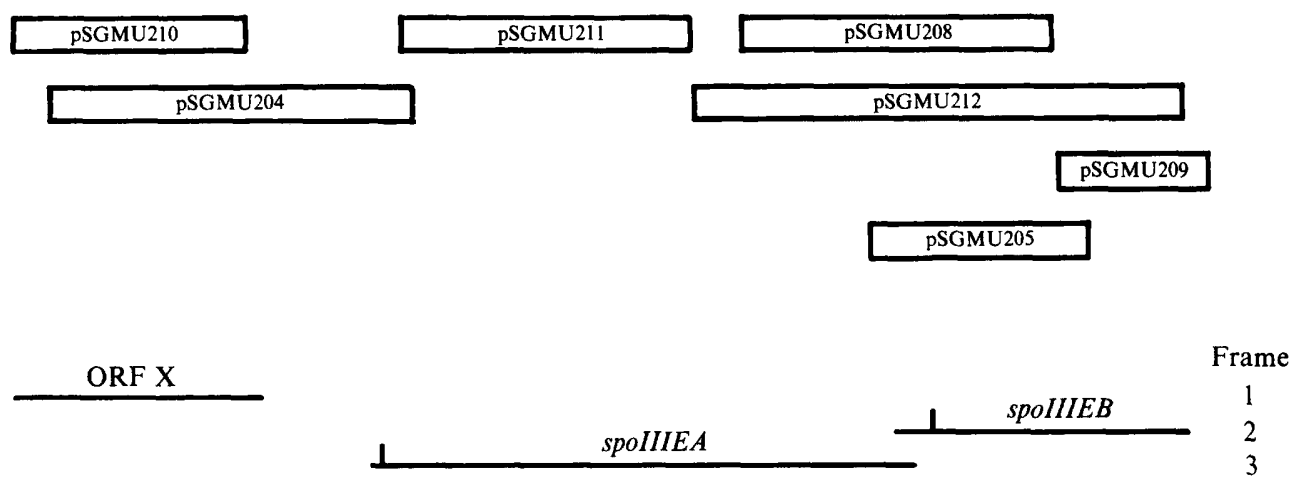

Fig. 4. Relationship between open reading frames in the spoIIIE region and the DNA fragments used in the integrational plasmid analysis. Translation start sites are indicated by the small vertical lines.

Plasmids pSGMU205, pSGMU208, pSGMU211 and pSGMU212 disrupted the spoIIIE locus so that the region covered by the inserts in these plasmids must be within the spoIIIE functional unit. However, plasmids pSGMU204 and pSGMU209 gave sporulation-positive chloramphenicol-resistant transformants. Both plasmids overlap the ends of the segment in the spoIIIE locus defined by pSGMU211 and pSGMU212. The opposite ends of the spoIIIE functional unit therefore appear to be in the fragments cloned in pSGMU204 and pSGMU209, although the latter, as already mentioned, does not contain any obvious transcriptiontermination signal after the coding region of the spoIIIEB gene.

RNA extracted from sporulating $B$. subtilis at various times after the induction of sporulation $\left(t_{0}-t_{3}\right)$ was analysed by 'Northern' hybridization with nick-translated pSGMU212 DNA as a probe. The probe contains a $1.4 \mathrm{kbp}$ SstI fragment which extends from position 1995 to 3422 of the sequence. An RNA species of about $2.5 \mathrm{~kb}$ was detected at $t_{3}$ (data not shown). If this represents transcripts initiated from the putative promoters listed in Table 4, it suggests that a transcription termination signal exists near the end of the region which was sequenced.

\section{DISCUSSION}

A $3.5 \mathrm{kbp}$ fragment of $B$. subtilis DNA capable of complementing the three known spoIIIE mutations has been sequenced. The spoIIIE locus was shown to consist of a dicistronic operon, thus adding another example to the list of sporulation loci which are known to contain more than one gene.

The deduced translation products of the two spoIIIE genes show several interesting characteristics. spoIIIEA codes for a large polypeptide of 518 amino acids $\left(M_{\mathrm{r}} 57300\right)$. There is a relative lack of acidic residues and quite a large number of hydrophobic residues. Most of the hydrophobic residues lie in the amino-terminal part of the protein. However, the extreme amino-terminal end is quite highly charged. The smaller spoIIIEB gene codes for a protein product which would be acidic (isoelectric point about 4.5) consisting of 252 amino acid residues $\left(M_{\mathrm{r}} 28100\right)$. Both cysteine and tryptophan are absent.

Codon usage (Wang \& Doi, 1986) in both genes is essentially 'average' for $B$. subtilis although several 'uncommon' codons are used at an increased frequency in the spoIIIEA gene.

The presence of several potential promoter structures which could be utilized by RNA polymerase containing $\sigma^{29}$ suggests that the expression of spoIIIE might be dependent on the processed spoIIG gene product (Trempy et al., 1985). This could be tested experimentally, as could a requirement for the sigma-factor-like gene product of the spoIIAC gene (Errington et al., 1985). Determination of the size of the spoIIIE message detected at $t_{3}$ suggests that a transcription-termination signal is close to the end of the region that was sequenced. An unusual feature of the spoIIIE operon is that the gap between the two genes is large - $50 \mathrm{bp}$ including the termination codon of spoIIIEA. In other sporulation operons that have been sequenced the 
reading frames are closer together or overlap (Fort \& Errington, 1985). However a large gap, $36 \mathrm{bp}$, has been reported between the P23 and dnaE genes in the $B$. subtilis major sigma factor operon (Wang \& Doi, 1986). The significance of such intercistronic regions which lack the potential to form secondary structures indicating potential RNA processing sites is not clear at present.

The requirement for spoIIIE gene products for the expression of three sporulation-related operons has been demonstrated. Mutations in spoIIIE prevent the expression of spoVA (Errington \& Mandelstam, 1986), ger $A$ (A. Moir, personal communication), and the $0.3 \mathrm{~kb}$ gene (Stephens et al., 1984) as demonstrated by lac Z fusion studies. Expression of the spoVA and gerA operons has been shown to occur only in the spore compartment. Conversely, the expression of sporulation genes that are known to occur only in the mother cell compartment is not blocked by mutations in the spoIIIE operon. For example, the synthesis of dipicolinic acid (DPA) by DPA synthase, the product of the spoVF locus, is not dependent on spoIIIE expression (J. Errington \& J. Mandelstam, unpublished results). This suggests that spoIIIE is part of a dependent sequence of operons expressed in the spore compartment. However, it is not yet known whether spoIIIE itself is expressed in the spore compartment or in the mother cell. The fact that protoplast fusion studies by Dancer \& Mandelstam (1981) showed partial complementation of the spoIIIE36 mutation by the wild-type suggests that it may be expressed in the mother cell with the implication that there is subsequently transport of the protein product(s) into the spore compartment. A more definite answer to the question should be obtainable by the use of spoIIIE : lac $Z$ fusions.

No homology of amino acid sequences between the spoIIIE gene products and any known regulatory protein could be found (Protein Sequence Database, NIH). Also no sequences in either polypeptide showed any significant similarity to known DNA-binding proteins, i.e. they did not seem to have the so-called ' $\alpha$-helix-turn- $\alpha$-helix motif' (Pabo \& Sauer, 1984). However, the failure to find such similarities does not rule out the possibility of a regulatory role for the proteins. Alternatively, the products of spoIIIE could have a physical effect on the assembly of spore components.

Thanks are due to Dr Jeff Errington for providing $\phi 105 J 30$ and $\phi 105 J 31$. This work was supported by the Science and Engineering Research Council.

\section{REFERENCES}

ANAgnostopoulos, C. \& Spizizen, J. (1961). Requirements for transformation in Bacillus subtilis. Journal of Bacteriology 81, 741-746.

BIRNBoIM, H. C. \& Doly, J. (1979). A rapid alkaline extraction procedure for screening recombinant plasmid DNA. Nucleic Acids Research 7, 15131523.

Cowing, D. W., Bardwell, J. C. A., Craig, E. A., WoOlford, C., Hendrix, R. W. \& Gross, C. A. (1985). Consensus sequence for Escherichia coli heat shock gene promoters. Proceedings of the National Academy of Sciences of the United States of America 82, 2679-2683.

Dancer, B. N. \& Mandelstam, J. (1981). Complementation of sporulation mutations in fused protoplasts of Bacillus subtilis. Journal of General Microbiology 123, 17-26.

ERRINGTON, J. (1986). A general method for fusion of the Escherichia coli lac $Z$ gene to chromosomal genes in Bacillus subtilis. Journal of General Microbiology 132, 2953-2966.

ERRINGTON, J. \& JoNES, D. (1987). Cloning in Bacillus subtilis by transfection with bacteriophage vector $\phi 105 \mathrm{~J} 27$ : isolation and preliminary characterization of transducing phages for 23 sporulation loci. Journal of General Microbiology 133, 493-502.
Errington, J. \& Mandelstam, J. (1983). Variety of sporulation phenotypes resulting from mutations in a single regulatory locus, spoIIA, in Bacillus subtilis. Journal of General Microbiology 129, 2091-2101.

ERrington, J. \& MANDELSTAM, J. (1986). Use of a lacZ fusion to determine the dependence pattern and the spore compartment expression of sporulation operon spoVA in spo mutants of Bacillus subtilis. Journal of General Microbiology 132, 2977-2985.

Errington, J., Fort, P. \& Mandelstam, J. (1985). Duplicated sporulation genes in bacteria. FEBS Letters 188, 184-188.

Fort, P. \& ERrington, J. (1985). Nucleotide sequence and complementation analysis of a polycistronic sporulation operon spoVA in Bacillus subtilis. Journal of General Microbiology 131, 1091-1105.

FORT, P. \& PIGGOT, P. J. (1984). Nucleotide sequence of sporulation locus spoIIA in Bacillus subtilis. Journal of General Microbiology 130, 2147-2153.

Gold, L., Pribnow, D., Schneider, T., Shinedling, S., SINGER, B. S. \& STORMo, G. (1981). Translational initiation in prokaryotes. Annual Review of Microbiology 35, 365-403.

Hoch, J. A. (1971). Selection of cells transformed to prototrophy for sporulation markers. Journal of Bacteriology 105, 1200-1201. 
Hranueli, D., Piggot, P. J. \& Mandelstam, J. (1974). Statistical estimate of the total number of operons specific for Bacillus subtilis sporulation. Journal of Bacteriology 119. 684-690.

JENKINSON, H. F. (1983). Altered arrangement of proteins in the spore coat of a germination mutant of Bacillus subtilis. Journal of General Microbiology 129, 1945-1958.

Jones, D. \& ERrington, J. (1987). Construction of improved bacteriophage $\phi 105$ vectors for cloning by transfection in Bacillus subtilis. Journal of General Microbiology 133, 483-492.

LOVETT, P. S. \& KegGINs, K. M. (1979). Bacillus subtilis as a host for molecular cloning. Methods in Enzymology 68, 342-357.

Maniatis, T., Fritsch, E. F. \& SambrooK, J. (1982). Molecular Cloning: a Laboratory Manual. Cold Spring Harbor, NY: Cold Spring Harbor Laboratory.

MARINUS, M. G. (1973). Location of DNA methylation genes on the Escherichia coli K12 genetic map. Molecular and General Genetics 127, 47-55.

MARTIN, R. B. (1964). Introduction to Biophysical Chemistry. New York \& San Francisco: McGraw Hill.

McLaughlin, J. R., Murray, C. L. \& Rabinowitz, J. C. (1981). Unique features in the ribosome binding site sequence of the gram-positive Staphylococcus aureus $\beta$-lactamase gene. Journal of Biological Chemistry 256, 11283-11291.

Messing, J. (1983). Mew M13 vectors for cloning. Methods in Enzymology 101, 20-78.

Messing, J., Crea, R. \& Seeburg, P. H. (1981). A system for shotgun DNA sequencing. Nucleic Acids Research 9, 309-321.

MurRay, C. L. \& Rabinowitz, J. C. (1982). Nucleotide sequences of transcription and translation initiation regions in Bacillus phage $\phi 29$ early genes. Journal of Biological Chemistry 257, 1053-1062.

Norrander, J., Kempe, T. \& Messing, J. (1983). Construction of improved M13 vectors using oligodeoxynucleotide-directed mutagenesis. Gene 26, 101-106.

Pabo, C. O. \& SAUER, R. T. (1984). Protein-DNA recognition. Annual Review of Biochemistry 53, 293321.

PIGGot, P. J. (1973). Mapping of asporogenous mutations of Bacillus subtilis: a minimum estimate of the number of sporulation operons. Journal of Bacteriology 114, 1241-1253.

Piggot, P. J., Curtis, C. A. M. \& Lencastre, H. DE (1984). Use of integrational plasmid vectors to demonstrate the polycistronic nature of a transcriptional unit (spoIIA) required for sporulation of Bacillus subtilis. Journal of General Microbiology 130 , 2123-2136.

SANGer, F., Nicklen, S. \& Coulson, A. R. (1977). DNA sequencing with chain-terminating inhibitors. Proceedings of the National Academy of Sciences of the United States of America 74, 5463-5467.

Savva, D. \& Mandelstam, J. (1984). Cloning of the Bacillus subtilis spoIIA and spoVA loci in phage $\phi 105 D I$ :1t. Journal of General Microbiology 130, 2137-2145.
Savva, D. \& Mandelstam, J. (1985). Use of cloned spoIIA and spoVA probes to study synthesis of mRNA in wild-type and asporogenous mutants of Bacillus subtilis. In Molecular Biology of Microbial Differentiation, pp. 55-59. Edited by P. Setlow \& J. Hoch. Washington: DC: American Society for Microbiology.

SCHAEFfer, P., IONESCo, H., RYter, A. \& Balassa, G. (1965). La sporulation de Bacillus subtilis: étude génétique et physiologique. Colloques Internationaux du Centre National de la Recherche Scientifique 124, 553-563.

Shine, J. \& Dalgarno, L. (1974). The 3'-terminal sequence of Escherichia coli $16 \mathrm{~S}$ ribosomal RNA: complementarity to nonsense triplets and ribosome binding sites. Proceedings of the National Academy of Sciences of the United States of America 71, 13421346.

SOUTHERN, E. M. (1975). Detection of specific sequences among DNA fragments separated by gel electrophoresis. Journal of Molecular Biology 98, 503-517.

StaDEN, R. (1982). Automation of the computer handling of gel reading data produced by the shotgun method of DNA sequencing. Nucleic Acids Research 10, 4731-4751.

STADEN, R. (1984a). A computer program to enter DNA gel reading data into a computer. Nucleic Acids Research 12, 499-503.

STADEN, R. (1984b). Graphic method to determine the function of nucleic acid sequences. Nucleic Acids Research 12, 521-538.

StePhens, M. A., Lang, N., Sandman, K. \& Losick, R. (1984). A promoter whose utilization is temporally regulated during sporulation in Bacillus subtilis. Journal of Molecular Biology 176, 333-348.

Sterlini, J. M. \& Mandelstam, J. (1969). Commitment to sporulation in Bacillus subtilis and its relationship to the development of actinomycin resistance. Biochemical Journal 113, 29-37.

TinoCo, I., Borer, P. N., DENGler, B., LeVine, M. D., Uhlenbeck, O. C., Crothers, D. M. \& Gralla, J. (1973). Improved estimation of secondary structure in ribonucleic acids. Nature New Biology 246, 40-41.

Trempy, J. E., Bonamy, C., Szulmaster, J. \& HaldenWANG, W. G. (1985). Bacillus subtilis sigma factor 29 is the product of the sporulation-essential gene spoIIG. Proceedings of the National Academy of Sciences of the United States of America 82, 41894192.

TURner, S. M., ERrington, J. \& Mandelstam, J. (1986). Use of a lacZ gene fusion to determine the dependence pattern of sporulation operon spoIIIC in spo mutants of Bacillus subtilis: a branched pathway of expression of sporulation operons. Journal of General Microbiology 132, 2995-3003.

W ANG, L.-F. \& DoI, R. H. (1986). Nucleotide sequence and organisation of Bacillus subtilis RNA polymerase major sigma $\left(\sigma^{43}\right)$ operon. Nucleic Acids Research 14, 4293-4307.

YANisCh-Perron, C., Viera, J. \& Messing, J. (1985). Improved M13 phage cloning vectors and host strains: nucleotide sequences of the $\mathrm{M} 13 \mathrm{mp} 18$ and pUC19 vectors. Gene 33, 103-119. 